\title{
Tapak Liman (Elephantopus scaber L) As Immunostimulant and Its Effect on Lymphocyte Differentiation in Mice BALB/C
}

\author{
Marmi Kelik \\ Faculty of Languages and Science, University of Wijaya Kusuma Surabaya, Indonesia
}

Author correspondency:

marni.kelik@yahoo.com

\begin{abstract}
Tapak liman (Elephantopus scaber L) is one of the plants that have medicinal properties and has been used for maintenance and improvement of health and disease treatment. The purpose of this study was to determine the effect of extracts of Tapak Liman (Elephantopus scaber L) as immunostimulant to the development of lymphocytes in mice BALB / C. The procedure of this study was to test aqueous extracts in vivo with various treatments (control, treatment of $0.5 \mathrm{~g} / \mathrm{kg}, 1.0 \mathrm{~g} / \mathrm{kg}, 2.0 \mathrm{~g} / \mathrm{kg}$ ) in healthy mice BALB / C for 2 weeks. After the treatment carried out analysis of the percentage and number of cells that express CD4+, CD8+ and CD4+ CD $8+$ in thymus organ, using flowcytometry. Analysis of data using one-way ANOVA followed Tukey's test with SPSS. From the analysis showed that the extract of Tapak liman at various doses showed no significant effect on the percentage expression of CD4 + CD8 + and CD4 + CD8 + in thymus organs. While the analysis of the number of cells, extracts of Tapak liman show its effect on the number of cells that express CD4+, $\mathrm{CD} 8+$ and CD4 + CD8 + in thymus organs. Concentration of $1.0 \mathrm{~g} / \mathrm{kg}$ of mice showed a good effect on the increase in T helper cells (CD4 $+)$, cytotoxic T cells $(\mathrm{CD} 8+)$ and Prothymosit cells $(\mathrm{CD} 4+\mathrm{CD} 8+)$.
\end{abstract}

Keywords: Tapak Liman, Immunostimulant, Lymphocyte

\section{Introduction}

Elephantopus scaber Linn, is a small herb, which grows in the wild throughout the tropical regions of the world. The major phytochemical constituents of the plant are elephantopin, triterpenes, stigmasterol, epofriedelinol and lupeol (Rastogi and Mehrotra, 1990; Kritikar and Basu, 1991). The plant has been used in the Indian system of medicine as analgesic, diuretic, astringent and antiemetic. The leaves of the plant were known to be used for bronchitis, small pox and diarrhea and as a brain tonic (Sankar et al., 2001). Recently, it has been shown to possess anti-inflammatory and anti tumour activity in animal models (Reico, 1989) and also found to have antibacterial activity against a few standard bacterial strains (Avani and Neeta, 2005).

The genus Elephantopus consists of approximately 30 species distributed in the Neotropicsand the Old World, and its lectotype species, E.scaber, occurs in all tropical regions (Cabrera and Klein, 1980; Chen, 1985; Cao and But, 1999). In Southern China, Hong Kong and Taiwan, the whole plant of E. scaber, a perennial herb, is well known as a folk medicine widely used in the treatment of nephritis, edema, dampness, chest pain, fever, pneumonia, scabies, and arthralgia due to wounding (Peer and Metzger, 1980; Hsu, 1986; Tsai andLin, 1999). In Brazil, the infusion and the decoction of the whole plant are used to stimulate diuresis, reduce fever, and eliminate bladder stones (Cabrera and Klein, 1980; Poli et al., 1992). It has also been popular as a medicinal herb in many countries of Southeast Asia, Latin America and Africa for a long time (Hammer and Johns, 1993; Cao et al., 1997).
Since the 1970's, a number of chemical constituents and pharmacological evaluations of E. Scaber have been reported. For example, Kurokawa et al. (1970) and Govindachari et al. (1972) reported elephantopin, deoxyelephantopin, and isodeoxyelephantopin in this species; De Silva et al. (1982) found that both alcoholic and chloroformic extracts of $E$. scaber contain cytotoxic germacranolide-type sesquiterpene lactones; Poli et al. (1992) tested the aqueous and hydroalcoholic extracts of whole plants for acute toxicity, analgesic, antipyretic, anti-inflammatory, cardiovascular, diuretic, and constipating activities; Hammer and Johns (1993) reported that the plant extract of E. scaber was subjected to bioassays; Lin et al. (1995) and Tsai and Lin (1999) evaluated the hepatoprotective and anti-inflammatory effects of the Taiwanese folk medicine "Teng-Khia-U", derived from three plant species including E. scaber, and But et al. (1997) described the isolation and structure elucidation of three germacranolide sesquiterpene lactones from $E$. scaber.

The E. scaber roots and leaves aqueous extracts showed excellent hypoglycemic effect in diabetic rats by lowering the blood glucose level and serum insulin level. A decrease in the elevated levels of glycosylated hemoglobin, liver glycogen, triglycerides and cholesterol serum in alloxan-induced hyperglycemic rats was also reported by Daisy et al. (2007).

Besides hypoglycemic activity in mice models, aqueous extract of E. scaber also showed significant antiinflammatory effect in both experimental acute and chronic arthritis rat models. The aqueous extract from the whole plant significantly inhibited the development of pad swelling in the acute experimental arthritis rats at a dose of $300 \mathrm{mg} / \mathrm{kg}$ while higher concentration of the 
extract $(500 \mathrm{mg} / \mathrm{kg})$ was required to inhibit the development of chronic joint swelling in the chronic inflammatory model (Tsai and Lin, 1999).

During thymocyte development, immature thymocytes that express both CD4 and CD8 genes must choose either a helper $\mathrm{CD}^{+}$or cytotoxic $\mathrm{CD} 8^{+} \mathrm{T}$-cell fate. Over the past two years, there have been some important advances regarding $\mathrm{T}$-cell lineage choice, including the identification of transcription factors required for $\mathrm{CD} 4$ gene silencing by $\mathrm{CD} 8$-lineage cells (RUNX3) or for $\mathrm{CD}^{+}{ }^{+}$-cell differentiation (GATA3), and a better understanding of how T-cell receptor (TCR) signalling correlates CD4/CD8-lineage differentiation to MHC specificity. This review summarizes these recent advances and highlights potential links between TCR signals and nuclear effectors of lineage differentiation (Bosselut R, 2004)

The purpose of this study was to determine the effect of extracts of Tapak Liman (Elephantopus scaber L) as imunostimulant to the development of lymphocytes in mice $\mathrm{BALB} / \mathrm{C}$.

\section{Materials and Methods}

This experiment used 4 groups, 1 group control and 3 treatment groups, with simple randomization. The samples taken at random (random) of the population reached the inclusion criteria as follows: murinestra in BALB/C female, age 6 weeks, and healthy. 12 mice $\mathrm{BALB} / \mathrm{C}$ as are divided into 4 groups, each group consists of three mice. Each group of mice is given the same standard food and drink ad libitum.

Four groups of mice are given: Control $(\mathrm{K})$ : aquades without extract of Tapak Liman leaf Treatment1 (P1): Tapak Liman leaf extract 0.5 grams $/ \mathrm{kg}$ body weight/day Treatment2 (P2): Tapak Liman leaf extract $1.0 \mathrm{~g} / \mathrm{kg}$ body weight/day Treatment3 (P3): Tapak Liman leaf extract $2.0 \mathrm{~g} / \mathrm{kg}$ body weight/day.

The effect of extracts on the development of lymphocytes in thymus can be determined by measuring the percentage and number of lymphocytes expressing the express $\mathrm{CD} 4{ }^{+}, \mathrm{CD} 8{ }^{+}$and $\mathrm{CD} 4^{+} \mathrm{CD} 8{ }^{+}$in thymus organ using flowcytometry on the 16th day, after the treatments of Tapak Liman extract at various doses. The data obtained in the form of percentage and number of cells that express the $\mathrm{CD}$ will be analyzed statistically by calculating the standard deviation in each treatment and one-way ANOVA analysis to determine the effect of treatment on the development of lymphocytes. If there are significant differences in each treatment, Tukey test would be done. Analysis were done using SPSS with a P value $<0.05$.

\section{Results and Discussion}

Thymus is the primary lymphoid organs, bone marrow as a producer of $\mathrm{T}$ cell precursors are derivatives of progenitor cells after differentiation in the thymus to form a functional $\mathrm{T}$ cells, and after 4 stages of maturation involves a variety of protein expression and $\mathrm{T}$ cell receptor (TCR) as an end to the circulation cell $\mathrm{T}$ peripherals (Keer, 1998).

Transitional stages of thymocyte maturation can be characterized on phenotip cells with the TCR-CD3 complex, the presence of $\mathrm{CD} 4$ and $\mathrm{CD} 8$ coreceptor (Kuper et al., 2002).

Based on the results of flowcytometry analysis (Figure 1) Note that the percentage of CD4 + expression on the control has an average value of $13: 04 \%$, in the treatment of $0.5 \mathrm{~g} / \mathrm{kg}$ had a mean value $10.67 \%$, in the treatment of $1.0 \mathrm{~g} / \mathrm{kg}$ had an average of $9.85 \%$. While on treatment of $2.0 \mathrm{~g} / \mathrm{kg}$ had an average of $10.81 \%$. Based on the results of statistical analysis using one-way ANOVA (Appendix 8) found that the expression of CD4 + , with a significance value of $0864(>0.05)$. For the expression of CD8 + with a significance value $0676(>$ 0.05), whereas for the expression of CD4 + CD8 + has a significance value $0.496(>0.05)$. It could be argued that there is no real influence liman extract of tread on all expressions of concentration versus percentage of CD4 +, $\mathrm{CD} 8+, \mathrm{CD} 4+\mathrm{CD} 8+$ in thymus organs.

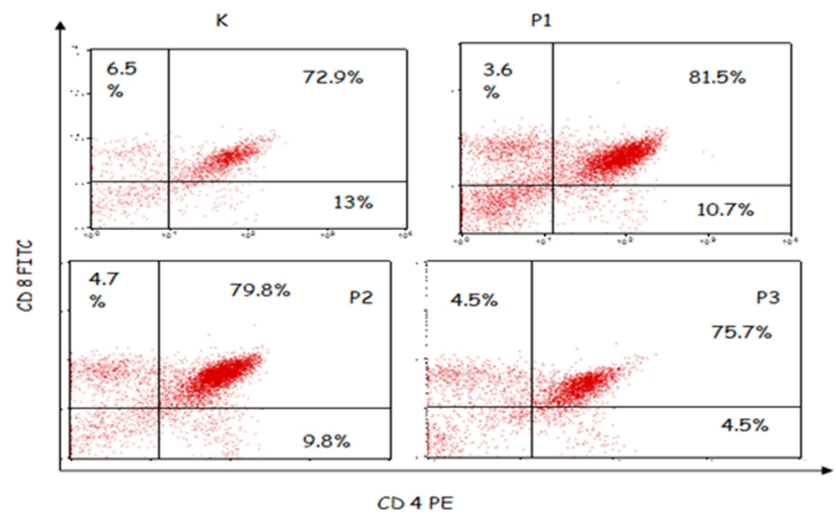

Figure 1. Cell Profile CD4+, CD8+ and CD4+ CD8+: Prosentage cell exspression $\mathrm{CD} 4+, \mathrm{CD} 8+, \mathrm{CD} 4+\mathrm{CD} 8+$ on thymus. Control (K), (P1:0.5 gr/kgbw), (P2:1.0 gr/kg bw), (P3:2.0 gr/kg bw).

Total cells (Figure. 2) shows that the concentration of $1.0 \mathrm{~g} / \mathrm{kg}$ increased the number of $\mathrm{CD}^{+}$cells (1615946) when compared to the control and the concentration of $0.5 \mathrm{~g} / \mathrm{kg}$ (976 610). Concentration of $2.0 \mathrm{~g} / \mathrm{kg}$ would reduce the number of cells that express $\mathrm{CD}^{+}(1438173)$ but still better than in the control and treatment of 0.5 $\mathrm{g} / \mathrm{kg}$. Likewise, the $\mathrm{CD}^{+}$cells that express at a concentration of $1.0 \mathrm{~g} / \mathrm{kg}$ caused the number of $\mathrm{CD} 8^{+}$cells at high (764 786) when compared to controls, $0.5 \mathrm{~g} / \mathrm{kg}$, $2.0 \mathrm{~g} / \mathrm{kg}$. Concentration of 2.0 shows thedecline inthe number of cytotoxic cells but still higher when compared with the concentration of $0.5 \mathrm{~g} / \mathrm{kg}$ and control. So it can be said that the concentration of $2.0 \mathrm{~g} / \mathrm{kg}$ gave the best effect on the number of cytotoxic cells in mouse thymus organs. Total cells that express $\mathrm{CD}^{+} \mathrm{CD}^{+}$ (prothymocyte) showed that consentration $1.0 \mathrm{~g} / \mathrm{kg}$ showed the best effect when compared with control (7395966) and the treatment of $0.5 \mathrm{~g} / \mathrm{kg}(7,455,115)$, and 
$2.0 \mathrm{~g}$ treatment $/ \mathrm{kg}$. Showed that the concentration of $1.0 \mathrm{~g} / \mathrm{kg}$ increased the number of cells prothymocyte.

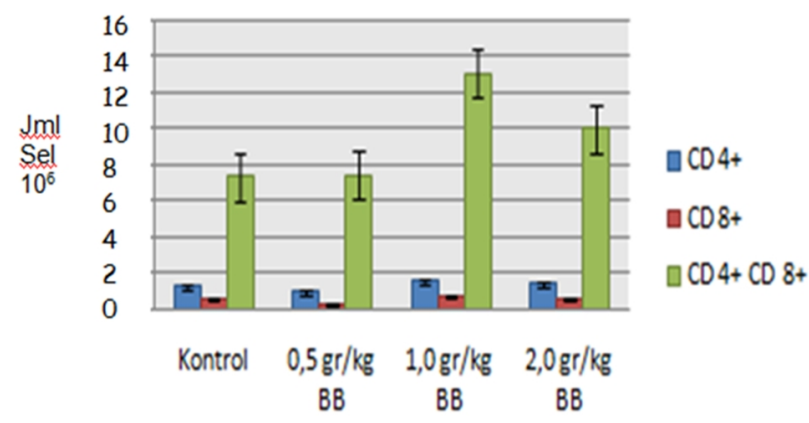

Figure 2. Total cell $\mathrm{CD} 4+, \mathrm{CD} 8+, \mathrm{CD} 4+\mathrm{CD} 8+$ on Thymus at Control, $0.5 \mathrm{gr} / \mathrm{kg}$ bw, $1.0 \mathrm{gr} / \mathrm{kg} \mathrm{bw}$, and $2.0 \mathrm{gr} / \mathrm{kg}$ bw.

Lymphocyte progenitor cells derived from bone marrow, some of which are relatively non-lymphocyte differentiation have migrated to the thymus and reproduce themselves, here is to obtain properties of lymphocytes $\mathrm{T}$ lymphocytes At first thymosit not express CD4 and CD8, cells then develop into double positive $\left(\mathrm{CD} 4{ }^{+} \mathrm{CD}^{+}\right)$and eventually mature into single positive $\left(\mathrm{CD} 4^{+}\right.$or $\left.\mathrm{CD}^{+}\right)$can then log back into the blood stream, back into the bone marrow or lymphoid organs and peripheral can live several months or years (Schwarz and Bandola, 2008).

\section{Conclusion}

Extract of Tapak liman at various doses showed no significant effect on the percentage expression of CD4 + $\mathrm{CD} 8+$ and CD4 + CD8 + in thymus organs and CD4 + $\mathrm{CD} 8+$ in thymus organs. While the analysis of the number of cells, extracts of Tapak liman show its effect on the number of cells that express CD4 +, CD8 + and CD4 + $\mathrm{CD} 8+$ in thymus organs. Concentration of $1.0 \mathrm{~g} / \mathrm{kg}$ of mice showed a good effect on the increase in $\mathrm{T}$ helper cells $(\mathrm{CD} 4+)$, cytotoxic $\mathrm{T}$ cells $(\mathrm{CD} 8+)$ and Prothymocyte cells (CD4 + CD8 +).

\section{References}

Avani, K. and S. Neeta, 2005. A study of the antimicrobial activity of Elephantopus scaber. Indian J. Pharmacol., 37: 126-127.

BosselutR, 2004. CD4/CD8-lineage differentiation in the thymus: from nuclear effectors to membrane signals, Nature Reviews Immunology 4, 529-540 (July 2004) | doi: 10.1038/nri1392

But P.-P.-H., Hon P.-M., Cao H., Chan T.-W.-D., Wu B.Kurokawa T., Nakanishi K., Wu W., Hsu H.-Y., Maruy-M., Mak T.-C.-W., and Che C.-T. (1997), Sesquiter- ama M., and Kupchan S.-M. (1970), Deoxyelephanpenelactones from Elephantopus scaber. Phytochem- topin and its interrelation with elephantopin. Tetraheistry 44, 113D116. dron Lett. 33, 2863D2866.

Cabrera A.-L. and Klein R.-M. (1980), Flora Ilustrada Lin C.-C., Tsai C.-C., and Yen M.-H. (1995), The eva-Catarinense: Compositae. 3. Tribo: Vernoniae, VI. luation of hepatoprotective effects of Taiwan folk Genero: Elephantopus. Itaja1', Brasil, pp. 397D402. Medicine "Teng-Khia-U”. J. Ethnopharm. 45, 113D

Daisy P, Rayan NA, Rajathi D (2007). Hypoglycemic and other related effects of Elephantopus scaber extracts on alloxan induced diabetic rats. J. Biol. Sci. 7: 433-437.

Hammer M.-L.-A. and Johns E.-A. (1993), Tapping an ered in La Gomera, Canary Islands, Spain. J. Chro-Amazonian plethora: four medicinal plants of Marajo mat. A 1011, 241D244. Island, Para (Brazilourna). J. Ethnopharm. 40, 53D75.

Kritikar, K.R. and B.D. Basu, 1991. Indian Medicinal Plants. 2nd Edn, Allahabad Publisher, Lalit Mohan Basu,.Livermore, D.M., T.G. Winstanley and K.P. Shannon, 2001. Interpretative reading; recognizing the unusual and inferring resistance mechanisms from resistance phenotypes. J. Antimicrob. Chemother, 48: 87-102.

Rastogi, R.P. and B.N. Mehrotra, 1990. Compendium of Indian Medicinal Plants. Vol. 1, Central Drug Research, Lucknow and National Institute of Science Communication, New Delhi.

Sankar, V., R. Kalirajan, F. Sweetlin Vivian Sales and S. Raghuraman, 2001. Antiinflammatory activity of Elephantopus scaber in albino rats. Indian J. Pharm. Sci., 63: 523-525.

Schwarz, B. A., Bandoola, A., 2006. Trafficking from Bone marrow to the Thymus: a Prerequisite for thymopoesis. Immunol rev.209: 47-54.

Tsai CC, Lin CC (1999). Anti-inflammatory effects of Taiwan folk medicine 'Teng-Khia-U' on carrageenan-and adjuvant-induced paw edema in rats. J. Ethnopharmacol. 64: 85-89.

Wang, L., Jian, S., Nan, P., Liu, J., Zhong, Y., 2005. Chemotypical variability of leaf oils in Elephantopus scaber from 12 locations in China. Chem. Nat. Compd.41: 491-493.

Waters, W.R., 2003. Expression ofL-Selectin (CD62L), CD44, and CD25 on Activated Bovine T Cells .Infect Immun. 71(1): 317326. 
